Article

\title{
Optimization of the Use of $\mathrm{His}_{6}-\mathrm{OPH}-$ Based Enzymatic Biocatalysts for the Destruction of Chlorpyrifos in Soil
}

\author{
Olga Senko, Olga Maslova (D) and Elena Efremenko* \\ Faculty of Chemistry, Lomonosov Moscow State University, Moscow 119991, Russia; senkoov@gmail.com (O.S.); \\ olga.maslova.rabota@gmail.com (O.M.) \\ * Correspondence: elena_efremenko@list.ru; Tel.: +7-495-9393170
}

Academic Editor: Assaf A. Abdelghani

Received: 30 October 2017; Accepted: 21 November 2017; Published: 23 November 2017

\begin{abstract}
Applying enzymatic biocatalysts based on hexahistidine-containing organophosphorus hydrolase ( $\left.\mathrm{His}_{6}-\mathrm{OPH}\right)$ is suggested for the decomposition of chlorpyrifos, which is actively used in agriculture in many countries. The application conditions were optimized and the following techniques was suggested to ensure the highest efficiency of the enzyme: first, the soil is alkalinized with hydrated calcitic lime $\mathrm{Ca}(\mathrm{OH})_{2}$, then the enzyme is introduced into the soil at a concentration of $1000 \mathrm{U} / \mathrm{kg}$ soil. Non-equilibrium low temperature plasma (NELTP)-modified zeolite is used for immobilization of the relatively inexpensive polyelectrolyte complexes containing the enzyme $\mathrm{His}_{6}-\mathrm{OPH}$ and a polyanionic polymer: poly-L-glutamic acid ( $\left.\mathrm{PLE}_{50}\right)$ or poly-L-aspartic acid $\left(\mathrm{PLD}_{50}\right)$. The soil's humidity is then increased up to $60-80 \%$, the top layer $(10-30 \mathrm{~cm})$ of soil is thoroughly stirred, and then exposed for $48-72 \mathrm{~h}$. The suggested approach ensures 100\% destruction of the pesticide within $72 \mathrm{~h}$ in soils containing as much as $100 \mathrm{mg} / \mathrm{kg}$ of chlorpyrifos. It was concluded that using this type of $\mathrm{His}_{6}$-OPH-based enzyme chemical can be the best approach for soils with relatively low humus concentrations, such as sandy and loam-sandy chestnut soils, as well as types of soil with increased alkalinity ( $\mathrm{pH}$ 8.0-8.4). Such soils are often encountered in desert, desert-steppe, foothills, and subtropical regions where chlorpyrifos is actively used.
\end{abstract}

Keywords: hexahistidine-containing organophosphorus hydrolase; soil; chlorpyrifos biodegradation; Dursban; agricultural pesticides; organophosphorus and organochlorine compounds

\section{Introduction}

The ever-continuing growth of the Earth's population is accompanied with an increasing demand for agricultural products: fruit, vegetables, cereals, meat, etc. Strategic development programs in many countries address the problem of stability and security of food supply and therefore support improvement of agricultural practices [1,2]. Development of animal husbandry and plant cultivation implies an increase of the areas used for grazing and hay harvesting as well as expansion of arable land and quick deforestation of territories [3-5]. However, since most areas with humus-rich soils are already being used in agricultural processes, such development calls for increasing use of steppes and deserts, which heretofore have been largely usused. This, in turn requires optimization of plant cultivation practices on relatively poor soils in terms of organic and mineral composition, such as sandy and loam-sandy chestnut soils [6].

The trend towards higher economical efficiency has led to the widespread utilization of organophosphorus and organochlorine agricultural pesticides as an inevitable part of modern agricultural practices. The application of pesticides against various plant pests is currently well founded from the economical viewpoint [7-10]. Chlorpyrifos in the form of the commercial chemical 
Dursban is a broad-spectrum chlorinated organophosphate insecticide, nematicide, and acaricide. The chlorpyrifos demand has increased annually [11] due to this pesticide's high efficiency and low market price. Chlorpyrifos-based chemicals are widely used in agriculture in many countries [6,7,11,12], oftentimes for cultivating palms and other plants in subtropical regions on soils with poor humus content $[13,14]$.

The toxicity of chlorpyrifos is rather high compared to that of other organophosphate pesticides, and so is its half-life, which can be (depending on many factors) as long as 120 days [11]. The non-decomposed residual chlorpyrifos presents a great hazard [15], because this chemical affects the soil biocenosis inhabitants [16-18]. The residual pesticide is leached from the soil and ends up in water bodies; besides, in can be carried via forage into the organisms of agricultural animals [19] and also get into humans via the food chain or by other means, which has a negative impact on human health $[20,21]$. One of the most common human exposure pathways to the pesticide is directly through pesticide-contaminated surface soil. Humans can be thus exposed to pesticides by ingesting soil, inhaling soil dust, and through dermal contact [20], especially for children [21].

The gravest health consequences are registered for agricultural workers and the general populace in the vicinity of pesticide application sites [11,19,22-24]. The removal of residual chlorpyrifos from the soil is one of the possible solutions for preventing the negative impact of this chemical on humans and animals. Thus, the search for efficient techniques for destroying the non-decomposed chlorpyrifos residues in various media (including soil) is a topical problem for researchers [11,25-28].

The existing techniques for purification of pesticide-polluted soils can be classified as in-situ (on-site purification of soils) and ex-situ ones (soil removal, purification at remote facilities, followed by returning of the soil to the original location) [29]. The former technique is easier to realize. The second classification type is further divided according to the method involved into non-biological (chemical, thermal, or physico-chemical) of biological ones (or their combination). However, the modern requirements for environmental safety make introduction into the soil of other active substances, e.g., strong oxidizers, an inacceptable solution, therefore biological soil purification techniques are preferred [30]. The toxicity of pesticide-contaminated soils can be reduced by remediation processes involving the use of microbes (bioremediation) [31-33], plants (phytoremediation) [34,35], plant-microorganism associations and extracellular and/or cell-free enzymes. Cells degrade or use the pesticides by various co-metabolic processes [36,37]. Many microorganisms and other soil inhabitants can efficiently decompose chlorpyrifos [11]. Soil bioremediation techniques involving the use of live organisms have a number of essential limitations. Bioremediation of soils with relatively poor humus content is especially difficult because the live cells used in the process lack sustenance. However, this type of soils is becoming increasingly involved in the agricultural process [38,39]. The use of extracellular and/or cell-free enzymes has been proposed as a remediation technique to purify such soils. The best results are achieved when using enzymes in immobilized form [40-43]. The immobilized enzymes have higher stability, they help ensuring high biocatalyst concentration in the immediate vicinity of the pollutant, which facilitates destruction of the latter. The enzymes are highly selective in their activity, and the corresponding chemicals are easy to standardize and store. The enzymes are more mobile compared to microorganism cells, and can preserve their activity in the presence of both high and low concentration of toxic substances [44].

The enzymatic biocatalysts based on hexahistidine-containing organophosphorus hydrolase $\left(\mathrm{His}_{6}-\mathrm{OPH}\right)$ are very useful for the elimination of organophosphorous compounds (OPCs) accumulating in soils treated with pesticides, since the enzyme has a wide enough range of activity and is capable of hydrolyzing various OPCs and even their destruction products $[43,45,46]$.

Since the pH optimum of $\mathrm{His}_{6}-\mathrm{OPH}$ action (10.5) [47] is significantly higher than the neutral value, which is typical for most soils, some additional stabilization of the enzyme introduced into the soil should be undertaken. The stabilization of the activity of $\mathrm{His}_{6}-\mathrm{OPH}$ enzyme can be achieved by sorption immobilization on a carrier, but also by the formation of the enzymatic polyelectrolyte complexes (EPCs) $[45,48,49]$. Such EPCs can be produced by simple mixing of the enzyme and 
polymer solutions that act as oppositely charged ion exchangers, and the optimum concentrations of the respective substances are to be found experimentally.

The search for efficient soil purification techniques has led to the choice of poly-L-glutamic acid $\left(\mathrm{PLE}_{50}\right)$ and poly-L-aspartic acid $\left(\mathrm{PLD}_{50}\right)$ as polyanions for the formation of complexes with $\mathrm{His}_{6}-\mathrm{OPH}$. These preferences for certain complexes were based on the results of the previously performed computer design of EPCs [50]. The use of such amino acid polymers as the enzyme partners within the EPC appeared attractive because in the case of biodegradation of such complexes under ambient conditions, the release of amino acid residues should occur that could serve as digestible nitrogen sources for the soil microbiota, thus positively stimulating the distribution of indigenous microorganisms. The results of preliminary studies indicated the excellent perspectives of using His $_{6}$-OPH-based biocatalysts for bioremediation of soils polluted with paraoxon [43].

Thus, the purpose of this work was to develop a strategy for Dursban (chlorpyrifos) detoxification based on the use of relatively inexpensive polyelectrolyte complexes containing the enzyme $\mathrm{His}_{6}-\mathrm{OPH}$ and the polyanionic polymers poly-L-glutamic acid $\left(\mathrm{PLE}_{50}\right)$ or poly-L-aspartic acid $\left(\mathrm{PLD}_{50}\right)$, in various types of soil. The $\mathrm{His}_{6}$-OPH and its EPCs were used both in free and immobilized form. Immobilization was achieved via sorption in natural zeolite with improved sorption capacity owing to its modification by treatment with non-equilibrium low temperature plasma (NELTP) in a barrier discharge.

\section{Materials and Methods}

\subsection{Materials}

Natural zeolite (1.6 $\div 4.3 \mathrm{~mm}$ fraction) (ZAO Orel Zeolite, Oryol, Russia) was used as carrier for $\mathrm{His}_{6}-\mathrm{OPH}$ immobilization. Poly-L-glutamic acid sodium salt (PLE $\mathrm{P}_{50}$, molecular weight $(\mathrm{MW})=7500 \mathrm{Da})$ and poly-L-aspartic acid sodium salt $\left(\mathrm{PLD}_{50}, \mathrm{MW}=6800 \mathrm{Da}\right)$ (Alamanda Polymers, Huntsville, AL, USA) were used for forming the polyelectrolyte complexes of $\mathrm{His}_{6}-\mathrm{OPH}$ enzyme. We also used hydrated calcitic lime, $\mathrm{Ca}(\mathrm{OH})_{2}$ provided by "Ilishevskaya Selkhozkhimiya" MUE (Verkhneyarkeyevo, Bashkortostan, Russia), dolomite powder with total mass fraction of calcium and magnesium carbonates $\left(\mathrm{CaCO}_{3}+\mathrm{MgCO}_{3}\right) 80 \%$ provided by Gera LLC (Lytkarino, Russia) and birch ash provided by Vitaflor LLC (Krasnogorsk, Russia). Dursban 480 EC containing $480 \mathrm{~g}$ of chlorpyrifos (O, O-diethyl O-3, 5, 6-trichloro-2-pyridinyl phosphorothioate, CPY; Chemical Abstract Service number (CAS No.) 2921-88-2) per 1 L was produced by Dow AgroSiences LLC (Indianapolis, IN, USA), paraoxon and other reagents were purchased from Sigma (St. Louis, MO, USA). Soil samples were provided by the Soil Science Department of the Lomonosov Moscow State University (sand: $\mathrm{pH} 7.4 \pm 0.2 \%$, humidity $90 \pm 5 \%$, humus $0.0 \pm 0.2 \%$; grey forest: $\mathrm{pH} 6.5 \pm 0.3 \%$, humidity $71 \pm 4.5 \%$, humus $1 \pm 0.3 \%$; chestnut: $\mathrm{pH} 8.0 \pm 0.2 \%$, humidity $82 \pm 6 \%$, humus $2.1 \pm 0.1 \%$; chernozem pH $7.0 \pm 0.2 \%$ humidity $75 \pm 5 \%$, humus $6.7 \pm 0.4 \%$ ).

\subsection{Preparation for Analysis of Enzyme Samples and Enzyme Polyelectrolyte Complexes}

Recombinant Escherichia coli strain SG13009[pREP4] (Qiagen, Hilden, Germany) transformed by plasmid encoding $\mathrm{His}_{6}-\mathrm{OPH}$ [51] was used for enzyme production. Cells were cultivated, and the enzyme was isolated and purified as described previously [47,52].

Cell biomass ( $20 \mathrm{~g}$ ) was suspended in $50 \mathrm{mM}$ phosphate buffer $(\mathrm{pH} 8.0)(200 \mathrm{~mL})$ containing $0.3 \mathrm{M}$ $\mathrm{NaCl}$ and homogenized by sonication on ice. Cell debris was removed by centrifugation for $30 \mathrm{~min}$ at $14,000 \times g$. An equal volume of Ni-NTA agarose pre-equilibrated in $50 \mathrm{mM}$ phosphate buffer was added to the supernatant. The resulting suspension was packed in a chromatographic column $(5 \mathrm{~mL})$ and washed with $50 \mathrm{mM}$ phosphate buffer (pH 8.0) containing $300 \mathrm{mM} \mathrm{NaCl}$ and $10 \mathrm{mM}$ imidazole at the flow rate of $0.5 \mathrm{~mL} / \mathrm{min}$ until the absorbance $(\lambda=280 \mathrm{~nm})$ decreased to 0.01 . The enzyme was eluted by an imidazole concentration gradient (10-500 mM). Imidazole was removed from collected protein fractions by dialysis against $50 \mathrm{mM}$ phosphate buffer, $\mathrm{pH}$ 8.0, and after that the fractions were analyzed, and protein concentration and enzymatic activity were determined. 
The concentration of protein was determined by Bradford assay. The level of $\mathrm{His}_{6}$-OPH expression as well as homogeneity of enzyme preparations was estimated by electrophoresis under denaturing conditions in $12 \%$ polyacrylamide gel using a Miniprotean II cell (Bio-Rad, Hercules, CA, USA) followed by Coomassie Blue (R-250) staining. According to SDS-PAGE data, the homogeneity of $\mathrm{His}_{6}-\mathrm{OPH}$ was similar to that obtained previously (98\%) [52].

The purified preparation of $\mathrm{His}_{6}-\mathrm{OPH}$ was characterized as described previously [47] by enzymatic activity. The enzymatic activity was determined as described previously [47] with $10 \mathrm{mM}$ aqueous paraoxon solution at $405 \mathrm{~nm}$ using an Agilent $8453 \mathrm{UV}$-visible spectroscopy system (Agilent Technology, Waldbronn, Germany) equipped with a thermostated cell monitoring the accumulation of hydrolysis product, 4-nitrophenolate anion, at $25^{\circ} \mathrm{C}$ and $405 \mathrm{~nm}\left(\varepsilon 17,000 \mathrm{M}^{-1} \cdot \mathrm{cm}^{-1}, \mathrm{pH} 9.0\right.$; $\left.\varepsilon 18,000 \mathrm{M}^{-1} \cdot \mathrm{cm}^{-1}, \mathrm{pH} 10.5\right)$. One unit of enzymatic activity (U) was defined as the quantity of the enzyme necessary to hydrolyze $1 \mu \mathrm{mol}$ of paraoxon per min at $25^{\circ} \mathrm{C}$. The specific activity of the purified enzyme was $4340 \mathrm{U} \cdot$ protein $\cdot \mathrm{mg}^{-1}$.

To obtain EPC, the $\mathrm{PLE}_{50}$ or PLD 50 solution aliquot prepared in distilled water at a concentration of $20 \mathrm{mg} \cdot \mathrm{mL}^{-1}$ was added to the solution of highly purified His ${ }_{6}-\mathrm{OPH}$ enzyme in $0.1 \mathrm{M}$ phosphate buffer ( $\mathrm{pH}$ 7.5) (protein concentration $0.16 \pm 0.01 \mathrm{mg} \cdot \mathrm{mL}^{-1}$, activity was $695 \pm 15 \mathrm{U} \cdot \mathrm{mL}^{-1}$ ). The aliquot volume was calculated so that the molar "enzyme:polymer" ratio was 1:5. Thereafter, the mixture was held for $30 \mathrm{~min}$ at $+8^{\circ} \mathrm{C}$. The effective hydrodynamic diameter of particles of the prepared complexes was determined at $25^{\circ} \mathrm{C}$ by DLS using a Zetasizer Nano ZS (Malvern Instruments Ltd., Malvern, UK) and was equal to $35 \pm 5 \mathrm{~nm}$.

\subsection{Immobilization Technique Processing of Mineral Carrier with Non-Equilibrium Low Temperature Plasma}

The original laboratory unit previously developed at the Moscow Institute of Physics and Technology and patented is equipped with a plasma generator [53], which provides the barrier discharge and non-equilibrium low temperature plasma, was used for the processing of the mineral carriers [43]. Several $1 \mathrm{~g}$ mineral samples were placed between the electrodes separated by a dielectric (quartz glass) and the NELTP generator was connected to the source. Then, in the zone for processing the raw material, an area of non-equilibrium low temperature plasma in a barrier discharge was produced; the voltage between the electrodes was up to $8000 \mathrm{~V}$, frequency was up to $40 \mathrm{kHz}$ [43]. The processing duration did not exceed $1.5 \mathrm{~min}$. The reduced electric field value $(\mathrm{E} / \mathrm{N})$ was $15 \times 10^{-16} \mathrm{~V} \cdot \mathrm{cm}^{-2}$, where $\mathrm{E}$ is electric field intensity, $\mathrm{N}$ is the total number of particles.

In order to obtain the immobilized enzyme preparation, $50 \mathrm{~mL}$ of the purified $\mathrm{His}_{6}-\mathrm{OPH}$ or the enzyme polyelectrolyte complex was mixed with $10 \mathrm{~g}$ of the mineral carrier and left at $8{ }^{\circ} \mathrm{C}$ for $6 \mathrm{~h}$ with periodic stirring [54]. Then the carrier was separated and washed with a solution containing $10 \mathrm{mM}$ of $\mathrm{NaHPO}_{4}$ and $5 \mathrm{mM}$ of $\mathrm{NaHCO}_{3}$ (pH 7.5) to constant residual activity of the immobilized enzyme. The specific activity of the produced chemicals was $231 \pm 5 \mathrm{U} / \mathrm{g}$ of dry carrier for $\mathrm{His}_{6}-\mathrm{OPH} / \mathrm{PLE}_{50}$ on zeolite and $236 \pm 5 \mathrm{U} / \mathrm{g}$ of dry carrier for $\mathrm{His}_{6}-\mathrm{OPH} / \mathrm{PLD}_{50}$ on zeolite. The dry weight of all the samples was determined according to the well-known method [55].

\subsection{Preparation of Soil and Its Treatment with Enzymatic Preprationss}

The development of the optimization technique was performed using sand soil, since positive results were previously obtained on fermentative decomposition of pesticides in soils of such type [42,43]. The treatment of the sand soil (initial humidity $90 \pm 5 \%$ ) for choosing the alkalizing agent was performed as follows: after introduction of the alkalizing agent (hydrated calcitic lime, dolomite powder, or birch ash) at a concentration of $10 \mathrm{~g} / \mathrm{kg}$ soil the soil was stirred, and $\mathrm{pH}$ level was measured after $15 \mathrm{~min}$. Soil $\mathrm{pH}$ was measured in a water suspension for each soil using a soil: solution ratio of 1:5 $\left(\mathrm{pH}_{\mathrm{w}}\right)$. When necessary, additional portions of the agent were added to achieve the $\mathrm{pH}$ level of 8.0-8.4. Then the solution of the enzymatic preparations of $\mathrm{His}_{6}-\mathrm{OPH}$ in $50 \mathrm{mM}$ phosphate buffer ( $\mathrm{pH}$ 8.0) with concentration of $300 \mathrm{U} / \mathrm{kg}$ soil was applied to the sample via surface sprinkling. The residual 
activity of the enzyme in the soil was determined in $1 \mathrm{~h}$ and $48 \mathrm{~h} \mathrm{[42]} \mathrm{and} \mathrm{the} \mathrm{pH}$ of the sample was measured. The samples were stored at $+24{ }^{\circ} \mathrm{C}$ in the course of this study.

In the course of the studies for optimizing the chlorpyrifos destruction process, Dursban was diluted with distilled water and sprayed on the soil samples. The final concentration of pesticide in all the soil samples was $100 \mathrm{mg}$ chlorpyrifos $/ \mathrm{kg}$ soil. $48 \mathrm{~h}$ after introduction of the Dursban into the soil sample the enzymatic destruction of the pesticide was initiated.

The study for choosing the most efficient form of $\mathrm{His}_{6}-\mathrm{OPH}$ application for sandy soil proceeded as follows: first, the soil's pH was increased up to $8.4 \pm 0.03$ using hydrated calcitic lime $\mathrm{Ca}(\mathrm{OH})_{2}$. Then NELTP-modified zeolite containing the immobilized $\mathrm{His}_{6}-\mathrm{OPH}$-containing agent was added to the soil, or $\mathrm{His}_{6}-\mathrm{OPH}$ was sprayed on the soil either in its free form or as complexes with polyelectrolytes. The specific activity of the enzyme chemicals introduced into the soil was 300-1000 U/ kg soil. Then the obtained substance was thoroughly mixed and exposed at room temperature for $48 \mathrm{~h}$. After the 48-h-long exposure the residual concentration of chlorpyrifos in the analytical samples was evaluated.

In the course of the study of chlorpyrifos destruction in various soil types by enzyme polyelectrolyte complexes $\mathrm{His}_{6}-\mathrm{OPH} / \mathrm{PLE}_{50}$ and $\mathrm{His}_{6}-\mathrm{OPH} / \mathrm{PLD}_{50}$ immobilized on zeolite the soil humidity was controlled; when necessary, the samples were wetted to keep the humidity at the level of $80 \pm 3 \%$, and stirred. The soil's humidity was evaluated with a TDR-100 professional humidity meter for soil and sand (Spectrum Technologies PLC, Bridgend, UK). Portions of the soil were taken at certain intervals and concentration of chlorpyrifos in them was analyzed.

\subsection{Determination of Chlorpyrifos Decomposition in Soil Samples}

In order to determine the concentrations of chlorpyrifos the pesticide was extracted from $3 \mathrm{~g}$ of soil with three portions of ethyl acetate $(5 \mathrm{~mL})$. The extracts were mixed, evaporated and dissolved in acetonitrile. Chlorpyrifos extracts were analyzed using HPLC (Knauer Smartline Pump 1000, Knauer Smartline UV Detector 2600, Berlin, Germany) and a Diasfer 110-C18 $5 \mu \mathrm{m}, 4.0 \times 250 \mathrm{~mm}$ reverse-phase chromatography column (Biochemmack CT, Moscow, Russia) with a spectrophotometric detector $(274 \mathrm{~nm})$ and isocratic elution. Acetonitrile-water mixture (60:40) was applied as the eluent. The retention time for chlorpyrifos was $31 \mathrm{~min}$. The eluent flow rate was $1 \mathrm{~mL} \cdot \mathrm{min}^{-1}$, and the detector cell temperature was $25^{\circ} \mathrm{C}$. The sample volume was $20 \mu \mathrm{L}$.

The concentration of chlorpyrifos degraded by enzyme preparation was calculated by the formula $\mathrm{Ce}=\mathrm{Cc}-\mathrm{Cd}$ [42], where $\mathrm{Ce}$ is the actual concentration of pesticide degraded by enzyme in soil, Cc is the pesticide concentration in soil without immobilized or non-immobilized enzyme (control), $\mathrm{Cd}$ is the determined pesticide concentration in soil with immobilized enzyme preparation.

\subsection{Assessment of Soil Samples Toxicity Using Photobacteria}

Bioluminescent photobacteria have been successfully applied for soil ecotoxicity assessment $[43,56]$. Therefore, in this study it was decided to analyze the overall toxicity of the soil samples using photobacteria cells immobilized in poly (vinyl alcohol) (PVA) cryogel. We have previous experience in the successful use of such cells for investigating carriers containing organophosphorus compounds, in addition to the control of paraoxon residue concentrations during its enzymatic decomposition in soil samples [57].

Photobacterium phosphoreum photobacteria immobilized in PVA cryogel were prepared according to the previously described method [57]. To evaluate the toxicity of all the soil samples, the ecotoxicant was extracted from the soil samples at $22 \pm 1{ }^{\circ} \mathrm{C}$ for $30 \mathrm{~min}$ on a thermostated shaker at a rate of $120 \mathrm{rpm}$ using $2 \%$ aqueous solution of $\mathrm{NaCl}$ containing $3 \%$ (vol.) ethanol, using $5 \mathrm{~mL}$ of an extractant per $0.35 \mathrm{~g}$ of soil. The obtained extract samples were analyzed for toxicity in discrete mode using immobilized photobacteria. The bioluminescence of the immobilized photobacteria was analyzed using a LKB 1250 luminometer (LKB Wallac, Turku, Finland) and its level was expressed in mV. Bioluminescence detection was performed in aqueous $2 \% \mathrm{NaCl}$ solution at $10 \pm 1{ }^{\circ} \mathrm{C}$. The initial level 
of cell luminescence was determined for $10 \mathrm{~s}$ at $10{ }^{\circ} \mathrm{C}$ after thermal equilibration of the system, and residual bioluminescence level was analyzed after $0.5 \mathrm{~h}$ upon exposure of immobilized photobacteria in the analyzed soil extract. The tests were performed in triplicate.

\subsection{Statistical Data Processing}

The data are presented as means of at least three independent experiments \pm standard deviation $( \pm \mathrm{SD})$. One-way ANOVA and Tukey test were applied. Statistical analysis was realized using SigmaPlot (ver. 12.5, Systat Software Inc., San Jose, CA, USA).

\section{Results}

3.1. The Choice of Conditions and Sequence of Operations to Increase the Efficiency of Applying His $_{6}-\mathrm{OPH}$-Based Enzyme Biocatalysts for Chlorpyrifos Degradation in Soil

$\mathrm{His}_{6}$-OPH functions efficiently at alkaline $\mathrm{pH}$ levels, while increasing the soil $\mathrm{pH}$ in excess of 8.5 can have a negative impact on the soil fertility. Therefore, hydrated calcitic lime, dolomite powder, and ash were tested for controlled increase of the soil $\mathrm{pH}$ up to 8.5 (Table 1). Sand soil with initial $\mathrm{pH}$ $7.4 \pm 0.2 \%$ was used. Special attention was paid to the possibility of achieving the soil $\mathrm{pH}$ of $8.0-8.4$ and keeping it in that range, as well as to the influence of the alkalizing agent on the stability of the enzymatic hydrolyzing activity towards organophosphorus pesticides.

Table 1. The choice of $\mathrm{pH}$ controlling agent in the course of choosing the scheme of applying $\mathrm{His}_{6}-\mathrm{OPH}$ for Chlorpyrifos destruction in soil.

\begin{tabular}{ccccc}
\hline \multirow{2}{*}{ pH Controlling Agent } & $\begin{array}{c}\text { Dose Introduced } \\
\text { into Soil (g/kg soil) }\end{array}$ & \multicolumn{2}{c}{ Soil pH after Introduction of Agent } & $\begin{array}{c}\text { Residual Activity of the Enzyme } \\
\text { upon Introduction into the Soil (\%) }\end{array}$ \\
\cline { 3 - 5 } & & In $\mathbf{1 5}$ min & In $\mathbf{4 8 ~ h}$ & In $\mathbf{1 ~ h}$ \\
\hline Control (no agent) & - & $7.4 \pm 0.02$ & $7.4 \pm 0.03$ & $84 \pm 2$ \\
Hydrated calcitic lime & $22 \pm 1$ & $8.4 \pm 0.03$ & $8.0 \pm 0.03$ & $93 \pm 2$ \\
Dolomite powder & $64 \pm 1$ & $8.2 \pm 0.05$ & $8.1 \pm 0.03$ & $91 \pm 2$ \\
Birch ash & $120 \pm 3$ & $8.1 \pm 0.02$ & $8.0 \pm 0.02$ & $91 \pm 2$ \\
\hline
\end{tabular}

The obtained data show (Table 1) that a smaller quantity of the agent was required to increase the soil $\mathrm{pH}$ to the target level when using hydrated calcitic lime than was the case with other alkalizing agents. Besides, the enzymatic activity in calcitic lime-containing soil remained higher during the $48 \mathrm{~h}$ upon introduction. It is also known from published data that introduction of $\mathrm{Ca}(\mathrm{OH})_{2}$ into the soil causes a decrease in bioaccessibility of heavy metals to the plant roots, and heavy metals can be present in the contaminated soils [58]. Thus, despite a slightly greater decrease of the soil's $\mathrm{pH}$ in $48 \mathrm{~h}$ upon introduction of $\mathrm{Ca}(\mathrm{OH})_{2}$ (compared with other alkalizing agents studied), hydrated lime dust can be recommended as the best choice as $\mathrm{pH}$ controlling agent for assisting the use of $\mathrm{His}_{6}$-OPH-containing preparations for Chlorpyrifos destruction.

The following procedure was suggested based on the analysis of both the published data and our own experiments. This procedure ensured the highest efficiency of Chlorpyrifos hydrolysis in soils using $\mathrm{His}_{6}$-OPH-based agent. First, $\mathrm{pH}$ of the soil was measured; then it was increased up to $8.4 \pm 0.03$ via introduction of hydrated calcitic lime $\mathrm{Ca}(\mathrm{OH})_{2}$; the soil was wetted up to $60-80 \%$ (when the initial humidity was below $60 \%$ ), the enzymatic agent was introduced, and the soil was thoroughly stirred to the depth of $10-30 \mathrm{~cm}$.

\subsection{Choice of the Form of the His ${ }_{6}-\mathrm{OPH}$-Based Biocatalysts for Introduction into Soils for Destroying Chlorpyrifos}

The possibility of decomposing $100 \mathrm{mg} / \mathrm{kg}$ soil of chlorpyrifos in model sandy soil was studied using various forms of enzymatic biocatalysts based on $\mathrm{His}_{6}-\mathrm{OPH}$. In the course of this study we adhered to the sequence of operations and the set of conditions formulated above. In $48 \mathrm{~h}$ upon 
introduction of the enzymatic biocatalysts the residual concentration of chlorpyrifos in the samples was assessed (Table 2).

Table 2. Residual concentration of chlorpyrifos (\%) in sand soil in $48 \mathrm{~h}$ upon introduction of the enzymatic biocatalysts into the soil *.

\begin{tabular}{|c|c|c|c|c|}
\hline \multirow{2}{*}{ Group } & \multirow{2}{*}{$\begin{array}{c}\text { Form of the Enzymatic } \\
\text { Biocatalysts }\end{array}$} & \multicolumn{3}{|c|}{ Initial Dose } \\
\hline & & $300 \mathrm{U} / \mathrm{kg}$ soil & $600 \mathrm{U} / \mathrm{kg}$ soil & $1000 \mathrm{U} / \mathrm{kg}$ soil \\
\hline 1 & $\mathrm{His}_{6}-\mathrm{OPH}$ & $74 \pm 4$ & $61 \pm 3$ & $48 \pm 3$ \\
\hline 2 & $\mathrm{His}_{6}-\mathrm{OPH} / \mathrm{PLD}_{50}$ & $48 \pm 2$ & $27 \pm 1$ & $13 \pm 0.5$ \\
\hline 3 & $\mathrm{His}_{6}-\mathrm{OPH} / \mathrm{PLE}_{50}$ & $43 \pm 2$ & $29 \pm 1$ & $8 \pm 0.3$ \\
\hline 4 & $\mathrm{His}_{6}-\mathrm{OPH} / \mathrm{PLD}_{50}$ on zeolite & $27 \pm 1$ & $19 \pm 0.5$ & 0 \\
\hline 5 & $\mathrm{His}_{6}-\mathrm{OPH} / \mathrm{PLE}_{50}$ on zeolite & $29 \pm 1$ & $17 \pm 0.5$ & 0 \\
\hline
\end{tabular}

* Residual concentration of chlorpyrifos in soil after $48 \mathrm{~h}$ without introduction of the enzymatic biocatalysts was $87 \pm 1 \%$.

The chlorpyrifos dose $(100 \mathrm{mg} / \mathrm{kg}$ soil) introduced into the model sand soil was chosen based on the concentrations of the pesticide Dursban recommended for application in agriculture $(0.8-3 \mathrm{~L} / \mathrm{ha})$ and the information that the non-decomposed chlorpyrifos can be accumulated in soil to reach concentrations as high as $100 \mathrm{mg} / \mathrm{kg}$ soil. The initial dose of the enzyme introduced into the soil was varied in the range of 300-1000 U/ kg soil using the data available to the authors concerning the results of enzymatic hydrolysis of paraoxon in soils [43] and the relation of the enzymatic activity towards paraoxon and chlorpyrifos [46]. Samples of the initial soil contaminated with pesticide but containing no enzymatic preparations were used as control. All the samples were wetted as stirred in the same way.

The differences in the mean values among the groups 1-5 (Table 2) are greater than would be expected by chance according to one-way analysis of variance (ANOVA), there is a statistically significant difference (for $300 \mathrm{U} / \mathrm{kg}$ soil and $600 \mathrm{U} / \mathrm{kg}$ soil $p=0.010$, for $1000 \mathrm{U} / \mathrm{kg}$ soil $p=0.008$ ). According to Tukey test, the differences in the mean values of $\mathrm{His}_{6}-\mathrm{OPH} / \mathrm{PLD}_{50}$ and $\mathrm{His}_{6}-\mathrm{OPH} / \mathrm{PLE}_{50}$ (300-600 U/kg soil) so as $\mathrm{His}_{6}-\mathrm{OPH} / \mathrm{PLD}_{50}$ and $\mathrm{His}_{6}-\mathrm{OPH} / \mathrm{PLE}_{50}$ on zeolites (300-1000 U/kg soil) were not great enough to exclude the possibility that the difference is due to random sampling variability, there was not a statistically significant difference $(p>0.05)$. In other comparisons there were statistically significant differences $(p<0.05)$, so the residual concentration of chlorpyrifos seems to be dependent of the form of the enzymatic biocatalysts.

Without considering the economic factors, the best dosage for destruction of chlorpyrifos in soil is $1000 \mathrm{U} / \mathrm{kg}$ soil, because it allows achieving $100 \%$ destruction of the pesticide within $48 \mathrm{~h}$ when polyelectrolyte complexes of $\mathrm{His}_{6}-\mathrm{OPH}$ are used. Thus, since the specific activity of the initial agents for $\mathrm{His}_{6}-\mathrm{OPH} / \mathrm{PLE}_{50}$ immobilized on zeolite was $231 \pm 5 \mathrm{U} / \mathrm{g}$ of dry carrier and that of similarly immobilized $\mathrm{His}_{6}-\mathrm{OPH} / \mathrm{PLD}_{50}$ was $236 \pm 5 \mathrm{U} / \mathrm{g}$ of dry carrier, introduction of $4 \mathrm{~g}$ of zeolite containing immobilized enzyme per $\mathrm{kg}$ of soil can be recommended for complete destruction of chlorpyrifos in soil. This is well within the norms recommended for the use of zeolites in agriculture, namely, up to $10-20$ volume $\%$ of the soil.

\subsection{The Chlorpyrifos Hydrolysis in Different Types of Soil}

The biocatalysts based on the natural zeolite processed with the NELTP for $1.5 \mathrm{~min}$, and the enzyme polyelectrolyte complexes $\mathrm{His}_{6}-\mathrm{OPH} / \mathrm{PLE}_{50}$ and $\mathrm{His}_{6}-\mathrm{OPH} / \mathrm{PLD}_{50}$, showed the best overall performance in terms of catalytic activity and stability against elution [43]. Therefore, they can be recommended for use in the agricultural technologies for the OPC decomposition. The poly-L-glutamic acid is more affected by hydrolytic enzymes than the poly-L-aspartic acid [59]. Therefore, the $\mathrm{His}_{6}-\mathrm{OPH} / \mathrm{PLE}_{50}$ biocatalyst was selected for the experiments on OPC decomposition in soils. 
It was argued that during the practical use such biocatalysts will undergo biodegradation easier under natural conditions upon completion of their primary function, i.e., hydrolysis of the OPC.

Using the suggested approach the kinetics of chlorpyrifos destruction in soils of various types was studied. Regular taking of samples was performed in the course of the experiment, and the residual chlorpyrifos content was evaluated, as well as enzymatic activity and soil humidity. When the humidity of the soil dropped below $50 \%$, the sample was additionally wetted by spraying.

It was found (see Figure 1a) that upon introducing the biocatalyst in a dose of $1000 \mathrm{U} / \mathrm{kg}$ into soils of different composition, the chlorpyrifos hydrolysis successfully occurred as early as during the first day (49-92\%). The complete decomposition was achieved within $72 \mathrm{~h}$ even when using the extremely high concentration of chlorpyrifos $\left(100 \mathrm{mg} \cdot \mathrm{kg}^{-1}\right.$ soil).
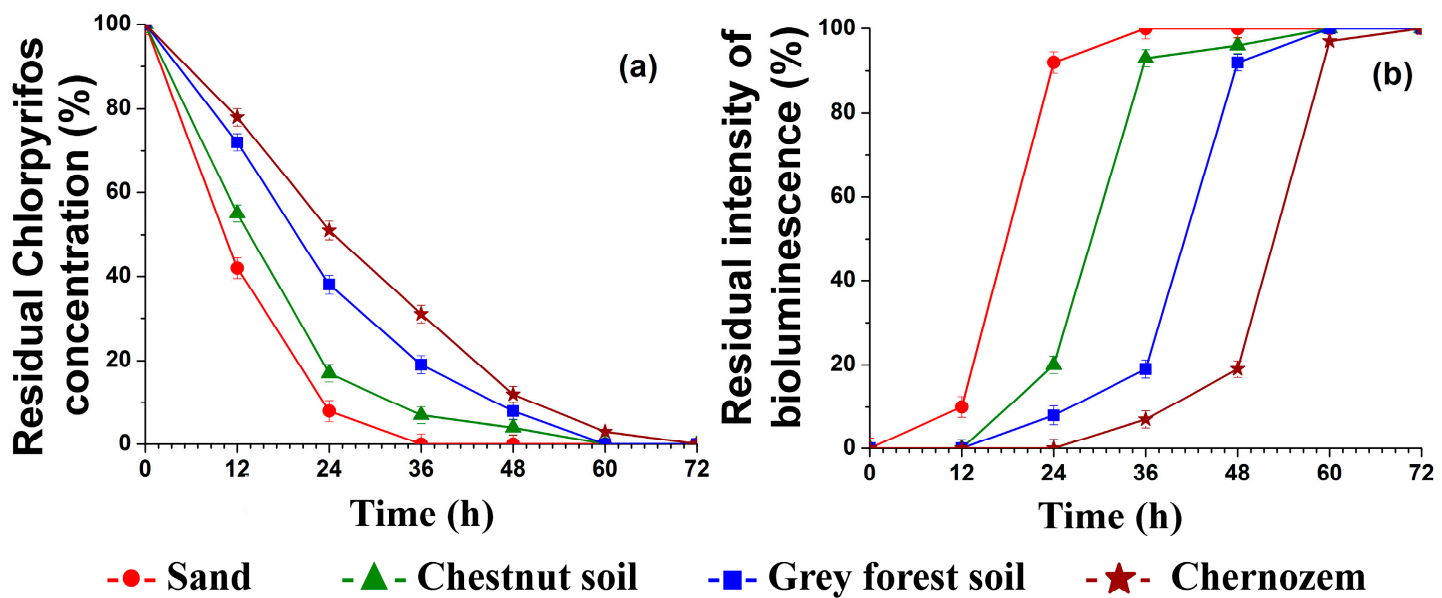

Figure 1. Destruction of $100 \mathrm{mg} \cdot \mathrm{kg}^{-1}$ soil of chlorpyrifos under the action of $\mathrm{His}_{6}-\mathrm{OPH} / \mathrm{PLE}_{50}$ immobilized in the plasma-modified (for $1.5 \mathrm{~min}$ ) natural zeolite in various types of soil (a) and residual bioluminescence of immobilized Photobacterium phosphoreum used for evaluating the residual toxicity of the treated soil samples (b).

When using photobacteria cells immobilized in the PVA cryogel, a toxicity assessment of the aqueous extracts made from the soil samples was conducted before and after the use of the $\mathrm{His}_{6}-\mathrm{OPH} / \mathrm{PLE}_{50}$-based biocatalyst. The results (Figure 1b) showed a complete absence of toxicity in soil samples within $72 \mathrm{~h}$ after the treatment with the enzyme biocatalyst. Similar results were obtained when testing (under the same conditions) the biocatalyst based on the natural zeolite processed with the NELTP for $1.5 \mathrm{~min}$ and the $\mathrm{His}_{6}-\mathrm{OPH} / \mathrm{PLD}_{50}$ polyelectrolyte complex containing poly-L-aspartic acid.

The results obtained for chlorpyrifos destruction by $\mathrm{His}_{6}$-OPH-based biocatalysts show that the hydrolysis occurs at a greater rate in soils with a relatively poor content of humic components (Figure 1a); these results are on the whole comparable with those obtained in the previous studies [42,43]. However, despite the differing rates of the hydrolysis process, the use of $\mathrm{His}_{6}-\mathrm{OPH}$-based biocatalysts in accordance with the suggested technique allows achieving $100 \%$ destruction of chlorpyrifos in soils of various types.

\section{Discussion}

The choice and the efficiency of the various techniques for purification of pesticides from soil essentially depends on the type of the soil and its physico-chemical characteristics: humidity, $\mathrm{pH}$, water- and air-permeability, etc. This was taken into account during the study for optimizing the techniques of applying enzymatic biocatalysts for destruction of chlorpyrifos (the basic component of the commercial chemical Dursban). Special attention was therefore paid to parameters such as soil humidity and $\mathrm{pH}$, the level of pesticide destruction in the soil depending on stirring, etc. 
Soil humidity influences the mobility of the pollutant and the structure of soil agglomerates. Water is also essential for the efficiency of biodegradation processes in soils, including those involving enzymatic biocatalysts. Thus, in order to optimize the conditions of chlorpyrifos hydrolysis catalyzed by $\mathrm{His}_{6}-\mathrm{OPH}$, the humidity of soil should be controlled and kept in the range of $60-80 \%$, which also facilitates plant growth [60]. Therefore, the technique for chlorpyrifos destruction with $\mathrm{His}_{6}-\mathrm{OPH}$-based agents in soils with humidity below $60 \%$ should include at least one wetting of the soil (e.g., by sprinkling) immediately before, during, or just after the introduction of the enzyme.

It is known that upon treatment of agricultural plants with chlorpyrifos the greater part of the pesticide is localized in the surface layer of the soil at the depth less than $30-40 \mathrm{~cm}$. Upon application of chlorpyrifos at $1.12 \mathrm{~kg} /$ ha the detected pesticide concentrations are $10 \mathrm{ppm}$ at $7.5 \mathrm{~cm}$ below the surface, $0.3 \mathrm{ppm}$ at $22.5 \mathrm{~cm}$, and $0.01 \mathrm{ppm}$ at the depth of $37.5 \mathrm{~cm}$ [61]. Thus, in order to optimize the catalysis process, the necessary condition for efficient chlorpyrifos destruction is soil stirring to the depth of $10-30 \mathrm{~cm}$. Standard agricultural appliances can be used for this purpose in the field conditions.

It is also known that organophosphorus pesticides are more efficiently hydrolyzed in an alkaline medium. Thus, an increase of soil $\mathrm{pH}$ from 6 to 8 causes an essential increase in the chlorpyrifos degradation rate (by a factor of 2-3) [12]. Besides, the optimal $\mathrm{pH}$ for $\mathrm{His}_{6}-\mathrm{OPH}$ activity is 10.5, and the effective working range is 7.5-11.5, which is in the alkaline domain. Therefore, in the course of pesticide hydrolysis by $\mathrm{His}_{6}$-OPH the main attention should be paid to maintaining control of the soil $\mathrm{pH}$ and keeping it above 7.0. Some of the soil types in the subtropical belt (e.g., humus-carbonate, carbonate alluvial, and marl soil) used for agricultural purposes where chlorpyrifos-based chemicals are currently applied are themselves slightly alkaline ( $\mathrm{pH} 8.0-8.4)$. The $\mathrm{pH}$ of acidic soils can be regulated by introducing the well-known and inexpensive substances extensively used for alkalizing, such as lime kiln, dolomite powder, ash, etc. However, to preserve the soil's fertility, its $\mathrm{pH}$ should be kept below 8.5. In the course of optimizing the enzymatic purification of soils it is important to choose such substances for controlling the soil's $\mathrm{pH}$ which would ensure stable functioning of the enzymatic biocatalysts in terms of catalytic action with respect to chlorpyrifos hydrolysis. Thus, before introducing $\mathrm{His}_{6}-\mathrm{OPH}$-based chemicals into the soil the $\mathrm{pH}$ of the latter should be checked. If $\mathrm{pH}$ is below 8.0, a substance routinely used in agriculture for soil alkalizing should be added to keep $\mathrm{pH}$ in the range of 8.0-8.4. In our study the best results were achieved for $\mathrm{Ca}(\mathrm{OH})_{2}$ (Table 1).

In the course of optimizing the techniques for soil purification from pesticides using enzyme-based biological methods the choice of the form of the biochemical agent which would be introduced into the soil is also important, because the agent's performance can be affected both by its form and by the environmental conditions. Two techniques were suggested and realized in the course of the experiments in order to stabilize the enzymatic activity, namely, inclusion of the enzyme into stable polyelectrolyte complexes based on polyaminoacids, and immobilization of these complexes on a mineral carrier, natural zeolite. It is important that all the components for the suggested technique are absolutely non-toxic towards soil and water biocenoses. The suggested methods are on the one hand based on the results obtained earlier and, on the other hand, thoroughly studied in the course of the current research on chlorpyrifos destruction in soils.

The use of enzymes with OPH activity in the immobilized form, in particular when adsorbed on natural cellulose-containing carriers [42,62], ensures a lasting high concentration of biocatalyst directly in the OPC localization. This technique also helps stabilizing the catalytic activity of the enzymatic biocatalyst at lower $\mathrm{pH}$ resulting from the accumulation of the ions $\mathrm{H}^{+}$released during the hydrolysis of the OPC.

The $\mathrm{His}_{6}$-OPH-containing straw-based immobilized enzymatic preparations developed earlier ensured decomposition of $630 \mathrm{mg}$ paraoxon or $850 \mathrm{mg}$ diazinon or $185 \mathrm{mg}$ parathion per $\mathrm{kg}$ soil in less than 10 days. The half-life of active biocatalyst in sand was estimated as 130 days [42]. However, the main drawback of these biocatalysts based on immobilized $\mathrm{His}_{6}-\mathrm{OPH}$ was their relatively low specific enzymatic activity per unit of the carrier, which was below $72 \mathrm{U} / \mathrm{g}$ of carrier. Enzyme interaction with cellulose-containing carriers was clearly caused by the capillary-porous structure 
of hygroscopic cellulose-containing material capable of retaining the enzyme solution within the macropores (in the lumens of plant cells-free moisture) or micropores (between the fibrils of the cytoderm-bound, or hygroscopic, moisture).

It is known that when applied to the soil in order to improve its structure, the zeolites are a source of natural mineral supplement that can significantly improve crop yields, help soil aeration and retain water in the root zone [63]. Low cost, high prevalence in nature, and usability as sorbents make such minerals as zeolites and perlites promising carriers for the enzyme, microbial biomass and organic matter (humic acids) immobilization and their use in agricultural technologies $[64,65]$. However, mineral carriers are characterized by relatively low protein adsorption capacity compared to cellulose-containing ones and do not result in effective enzymatic biocatalysts, including those based on organophosphorus hydrolase [42]. Therefore, the specific activity of biocatalysts produced using various mineral carriers (vermiculite, activated carbon, Sibunit, sand, diatomaceous earth) did not exceed $5 \mathrm{U} / \mathrm{g}$ of carrier, which is 14.4 times lower than that of the straw-based ones.

The non-equilibrium low temperature plasma (NELTP) processing in barrier discharge can positively affect the sorption characteristics of mineral carriers applied as building materials [66,67]. In general, plasma is an ionized gas that can be generated by a number of methods, including electric discharges (glow, microwave, plasma jet, radio frequency, etc.). Depending on their energy level, temperature, and ionic density, plasmas are usually classified as high temperature ones (for nuclear applications) and low temperature ones (including thermal and cold plasmas). The bulk temperature in cold plasmas can be as low as room temperature [68].

When applying the enzymatic polyelectrolyte complex containing the parent enzyme $\mathrm{His}_{6}-\mathrm{OPH}$ and poly-L-glutamic acid ( $\mathrm{PLE}_{50}$ ), immobilized on the plasma-modified (for $1.5 \mathrm{~min}$ ) natural zeolite, in a dose of $300 \mathrm{U} / \mathrm{kg}$ soil at the initial extremely high concentration of paraoxon of $650 \mathrm{mg} \cdot \mathrm{kg}^{-1}$ soil, complete lack of residual toxicity was achieved in a rather short time (after $180 \mathrm{~h}$ ) in all the tested soil samples [43]. The performed enzyme surface modification with polymers (due to the interaction of oppositely charged molecules of the enzyme and the polymer) resulted in the formation of complexes with high enzymatic activity and increased stability of the $\mathrm{His}_{6}-\mathrm{OPH}$. The use of polyanions when developing the enzyme polyelectrolyte complexes apparently does not directly affect the active center of the enzyme and has a positive effect on the preservation of the $\mathrm{His}_{6}-\mathrm{OPH}$ activity.

In the current study for optimization of $\mathrm{His}_{6}-\mathrm{OPH}$ application technique for chlorpyrifos destruction in soils the best results were also obtained for hydrolase in the form of polyelectrolyte complexes immobilized on zeolite (Table 2), which agrees well with the previously obtained data on paraoxon hydrolysis in soils [43]. Note that better results on neutralization of organophosphorus compounds in soils using $\mathrm{His}_{6}$-OPH-based agents were achieved in the current study, which is most probably due to the suggested approaches including the increasing of the soil $\mathrm{pH}$ to $8.0-8.5$ using special alkalizing agents and keeping the soil humidity above $60 \%$.

The results obtained show that application of the suggested optimized approach to chlorpyrifos destruction using $\mathrm{His}_{6}$-OPH-based enzymatic biocatalysts ensures more rapid pesticide neutralization than in case of using known microbial agents for this end. Thus, microbial biocatalyst for degradation of organophosphorus pesticides based on bacterial cells of Stenotrophomonas YC-1 strain was used in study [69] for detoxification of soil polluted with chlorpyrifos $(100 \mathrm{mg} / \mathrm{kg})$. This approach ensured a high enough initial chlorpyrifos degradation rate $\left(19 \mathrm{mg} / \mathrm{kg}_{\text {soil }} /\right.$ day $)$, but this rate was much lower than when using $\mathrm{His}_{6}$-OPH in soils of various types (49-92 mg/ $/ \mathrm{kg}_{\text {soil }} /$ day) (Figure 1a).

The possibility of microbial detoxification of soil polluted with chlorpyrifos at $50 \mathrm{mg} / \mathrm{kg}_{\text {soil }}$ was shown in [70]. Bacterial cells of the species Pseudomonas aeruginosa, Bacillus cereus, Klebsiella sp., Serratia marscecens were used as biological agents to destroy the pesticide. P. aeruginosa cells had the highest efficiency in bioremediation of the polluted soil. Other microorganisms studied caused slower degradation of chlorpyrifos. The main drawback of the suggested microbial remediation technique is that these bacteria are pathogens which can cause pneumonia, sepsis, infections of intestine and urogenital system, wound infections etc. with possible lethal consequences [71,72]. 
Another disadvantage of this technique is the great duration of the soil purification process, which limits the practical applicability of this method. This approach also requires introduction of additional carbon and nitrogen sources into the treated soil to facilitate the growth of the pesticide-decomposing microorganisms, which increases the total cost of this technique.

The most practically important result of the present study is the observation that the His $_{6}$-OPH-based biocatalysts can efficiently destroy chlorpyrifos in soils with poor humus content, where application of the traditional techniques involving live microbial consortia is limited. Thus the growing demand is observed in 21st century for the products of palm agriculture: palm and coconut oil, bananas, and dates. Agricultural palm plantations involve still newer regions with tropical and subtropical climate. The palm agriculture takes lead compared with other plant cultivation spheres in such countries as Pakistan [13,73]. Most of the soil resources in the subtropics are poor in humus content, lack structure, and are heavy in mechanical terms. The subtropical climate is nonetheless favorable for efficient growing of many useful agricultural products. Such territories, apart from palms, yield citrus fruit, persimmon, figs, pomegranates, olives, laurel, avocadoes, walnuts, almonds, pistachios, peaches, apples, and other fruit. Chlorpyrifos is often used in agriculture, and can be accumulated in soil, water, and agricultural produce. The strategy for enzymatic purification of soils from pesticides is perspective for bioremediation of such soils.

\section{Conclusions}

The optimized conditions and sequence of operations were found for using $\mathrm{His}_{6}-\mathrm{OPH}$ for destruction of chlorpyrifos in soils of various types. First stage was increasing the soil $\mathrm{pH}$ to 8.4 using hydrated calcitic lime $\mathrm{Ca}(\mathrm{OH})_{2}$. The second one is introduction into the soil of the enzyme preparation at $1000 \mathrm{U} / \mathrm{kg}$ soil (corresponding to $4 \mathrm{~g}$ zeolite $/ \mathrm{kg}$ soil) in the form of NELTP-modified zeolite with immobilized relatively inexpensive polyelectrolyte complexes containing the enzyme $\mathrm{His}_{6}-\mathrm{OPH}$ and polyanionic polymer: poly-L-glutamic acid ( $\mathrm{PLE}_{50}$ ) or poly-L-aspartic acid ( $\left.\mathrm{PLD}_{50}\right)$. The third one is wetting the soil to achieve $60-80 \%$ humidity, followed by through stirring of the soil to the depth of 10-30 cm and exposure for 48-72 h. In case of initial chlorpyrifos concentration of $100 \mathrm{mg} / \mathrm{kg}$ soil complete destruction of the pesticide is achieved within $72 \mathrm{~h}$ when using the optimized technique of enzymatic treatment.

Compared to the existing biological techniques for purification of soils from pesticides based on the use of live organisms, using His $_{6}$-OPH-based enzymatic biocatalysts was found to be preferable for humus-poor soils, such is sand and loam-sand chestnut soils, as well as those with alkaline $\mathrm{pH}$ (8.0-8.4), located in desert-steppe, foothill, and subtropical territories where chlorpyrifos is still actively used.

The suggested approach is based on technological operations which can be reproduced under the actual agricultural and farming conditions using standard equipment. This approach ensures the decrease of environmental risks and is aimed at preserving health of humans and animals, which promises the high market potential of the developed techniques. The economic feasibility of the suggested method is also based on the low cost of the fermentation agent, because the latter can be produced in quantity due to the use of highly productive bacterial strain with high yield of the His6-OPH ferment [51].

Acknowledgments: This work was supported by the Russian Science Foundation [Grant No. 16-14-00061].

Author Contributions: Olga Maslova, Olga Senko and Elena Efremenko conceived and designed the experiments; Olga Maslova and Olga Senko performed the experiments; Olga Maslova, Olga Senko and Elena Efremenko analyzed the data and wrote the paper. All authors approved the final version of the manuscript.

Conflicts of Interest: The authors declare no conflict of interest. The founding sponsor had no role in the design of the study; in the collection, analyses, or interpretation of the data; in the writing of the manuscript; and in the decision to publish the results. 


\section{References}

1. Tomlinson, I. Doubling food production to feed the 9 billion: A critical perspective on a key discourse of food security in the UK. J. Rural Stud. 2013, 29, 81-90. [CrossRef]

2. Cheeseman, J. Food security in the face of salinity, drought, climate change, and population growth. In Halophytes for Food Security in Dry Lands; Khan, M.A., Ozturk, M., Eds.; Academic Press, Amazon Digital Services LLC: Cambridge, MA, USA, 2015; pp. 111-123.

3. Su, S.; Zhou, X.; Wan, C.; Li, Y.; Kong, W. Land use changes to cash crop plantations: Crop types, multilevel determinants and policy implications. Land Use Policy 2016, 50, 379-389. [CrossRef]

4. Carlson, K.M.; Curran, L.M.; Ratnasari, D.; Pittman, A.M.; Soares-Filho, B.S.; Asner, G.P.; Trigg, S.N.; Gaveau, D.A.; Lawrence, D.; Rodrigues, H.O. Committed carbon emissions, deforestation, and community land conversion from oil palm plantation expansion in West Kalimantan, Indonesia. Proc. Natl. Acad. Sci. USA 2012, 109, 7559-7564. [CrossRef] [PubMed]

5. Ahrends, A.; Hollingsworth, P.M.; Ziegler, A.D.; Fox, J.M.; Chen, H.; Su, Y.; Xu, J. Current trends of rubber plantation expansion may threaten biodiversity and livelihoods. Glob. Environ. Chang. 2015, 34, 48-58. [CrossRef]

6. Sheng, H.; Zhou, P.; Zhang, Y.; Kuzyakov, Y.; Zhou, Q.; Ge, T.; Wang, C. Loss of labile organic carbon from subsoil due to land-use changes in subtropical China. Soil Biol. Biochem. 2015, 88, 148-157. [CrossRef]

7. Engindeniz, S.; Cosar, G.O. An economic comparison of pesticide applications for processing and table tomatoes: A case study for Turkey. J. Plant Prot. Res. 2013, 53, 230-237. [CrossRef]

8. Uqab, B.; Mudasir, S.; Nazir, R. Review on bioremediation of pesticides. J. Bioremediat. Biodegrad. 2016, 7, 3-8.

9. Antle, J.M. Pesticide Policy, Production Risk, and Producer Welfare: An Econometric Approach to Applied Welfare Economics; RFF Press, Routledge: Abingdon, UK, 2015; p. 128.

10. Sexton, S.E.; Lei, Z.; Zilberman, D. The economics of pesticides and pest control. IRERE 2007, 1, $271-326$. [CrossRef]

11. John, E.; Shaike, J. Chlorpyrifos: Pollution and remediation. Environ. Chem. Lett. 2015, 13, 269-291. [CrossRef]

12. Solomon, K.R.; Williams, W.M.; Mackay, D.; Purdy, J.; Giddings, J.M.; Giesy, J.P. Properties and uses of chlorpyrifos in the United States. In Ecological Risk Assessment for Chlorpyrifos in Terrestrial and Aquatic Systems in the United States; Giesy, J., Solomon, K., Eds.; Springer: Cham, Switzerland, 2014; pp. 13-34.

13. Radwan, E. The Current Status of the Date Palm Sector in the Gaza Strip, Palestine; LAP Lambert Academic Publishing: Saarbrücken, Germany, 2017; p. 156.

14. Ismail, B.S.; Halimah, M.; Tan, Y.A.; Tayeb, M.A. Dissipation of chlorpyrifos in a Malaysian agricultural soil: A comparison between a field experiment and simulation by the VARLEACH and PERSIST models. Sains Malays. 2017, 46, 21-26.

15. Chen, M.; Xu, P.; Zeng, G.; Yang, C.; Huang, D.; Zhang, J. Bioremediation of soils contaminated with polycyclic aromatic hydrocarbons, petroleum, pesticides, chlorophenols and heavy metals by composting: Applications, microbes and future research needs. Biotechnol. Adv. 2015, 33, 745-755. [CrossRef] [PubMed]

16. Medo, J.; Maková, J.; Kovácsová, S.; Majerčíková, K.; Javoreková, S. Effect of Dursban 480 EC (chlorpyrifos) and Talstar 10 EC (bifenthrin) on the physiological and genetic diversity of microorganisms in soil. J. Environ. Sci. Health B 2015, 50, 871-883. [CrossRef] [PubMed]

17. Sanchez-Hernandez, J.C.; Notario, D.P.J.; Capowiez, Y.; Mazzia, C.; Rault, M. Soil enzyme dynamics in chlorpyrifos-treated soils under the influence of earthworms. Sci. Total Environ. 2017, 612, 1407-1416. [CrossRef] [PubMed]

18. Bisht, J.; Harsh, N.S.K.; Palni, L.M.S.; Pande, V. Effect of repeated application of chlorpyrifos on fungal population of pine forest soil. Indian For. 2016, 142, 253-259.

19. Jallow, M.F.; Awadh, D.G.; Albaho, M.S.; Devi, V.Y.; Ahmad, N. Monitoring of pesticide residues in commonly used fruits and vegetables in Kuwait. Int. J. Environ. Res. Public Health 2017, 14, 833. [CrossRef] [PubMed]

20. Schinasi, L.; Leon, M.E. Non-Hodgkin lymphoma and occupational exposure to agricultural pesticide chemical groups and active ingredients: A systematic review and meta-analysis. Int. J. Environ. Res. Public Health 2014, 11, 4449-4527. [CrossRef] [PubMed]

21. $\mathrm{Li}, \mathrm{Z}$. Health risk characterization of maximum legal exposures for persistent organic pollutant (POP) pesticides in residential soil: An analysis. J. Environ. Manag. 2018, 205, 163-173. [CrossRef] [PubMed] 
22. Jennings, A.A.; Li, Z. Scope of the worldwide effort to regulate pesticide contamination in surface soils. J. Environ. Manag. 2014, 146, 420-443. [CrossRef] [PubMed]

23. Mostafalou, S.; Abdollahi, M. Pesticides and human chronic diseases: Evidences, mechanisms, and perspectives. Toxicol. Appl. Pharmacol. 2013, 268, 157-177. [CrossRef] [PubMed]

24. Shelton, J.F.; Geraghty, E.M.; Tancredi, D.J.; Delwiche, L.D.; Schmidt, R.J.; Ritz, B.; Hansen, R.L.; Hertz-Picciotto, I. Neurodevelopmental disorders and prenatal residential proximity to agricultural pesticides: The Charge study. Environ. Health Perspect. 2014, 122, 1103-1109. [CrossRef] [PubMed]

25. Wu, J.; Chen, X.; Ou, C.; Huang, C. Effect of micro-remediation on enzymes activity and available nutrients in chlorpyrifos-polluted soils. Agric. For. Fish. 2017, 6, 166-172.

26. Orts, A.; Cabrera, S.; Gómez, I.; Parrado, J.; Rodriguez-Morgado, B.; Tejada, M. Use of okara in the bioremediation of chlorpyrifos in soil: Effects on soil biochemical properties. Appl. Soil Ecol. 2017, 121, 172-176. [CrossRef]

27. Singh, B.K.; Walker, A.; Morgan, J.A.W.; Wright, D.J. Biodegradation of chlorpyrifos by Enterobacter strain B-14 and its use in bioremediation of contaminated soils. Appl. Environ. Microbiol. 2004, 70, 4855-4863. [CrossRef] [PubMed]

28. Dua, K.; Joshi, N. Effect of chlorpyrifos on soil microbial health. Int. J. Sci. Technol. 2015, 3, 259.

29. Castelo-Grande, T.; Augusto, P.A.; Monteiro, P.; Estevez, A.M.; Barbosa, D. Remediation of soils contaminated with pesticides: A review. Int. J. Environ. Anal. Chem. 2010, 90, 438-467. [CrossRef]

30. Morillo, E.; Villaverde, J. Advanced technologies for the remediation of pesticide-contaminated soils. Sci. Total Environ. 2017, 586, 576-597. [CrossRef] [PubMed]

31. Pino, N.; Peñuela, G. Simultaneous degradation of the pesticides methyl parathion and chlorpyrifos by an isolated bacterial consortium from a contaminated site. Int. Biodeterior. Biodegrad. 2011, 65, 827-831. [CrossRef]

32. Pailan, S.; Gupta, D.; Apte, S.; Krishnamurthi, S.; Saha, P. Degradation of organophosphate insecticide by a novel Bacillus aryabhattai strain SanPS1, isolated from soil of agricultural field in Burdwan, West Bengal, India. Int. Biodeterior. Biodegrad. 2015, 103, 191-195. [CrossRef]

33. Briceno, G.; Schalchli, H.; Mutis, A.; Benimeli, C.S.; Palma, G.; Tortella, G.R.; Diez, M.C. Use of pure and mixed culture of diazinon-degrading Streptomyces to remove other organophosphorus pesticides. Int. Biodeterior. Biodegrad. 2016, 114, 193-201. [CrossRef]

34. Henderson, K.L.; Belden, J.B.; Zhao, S.; Coats, J.R. Phytoremediation of pesticide wastes in soil. Z. Naturforsch. C 2006, 61, 213-221. [CrossRef] [PubMed]

35. Bert, V.; Seuntjens, P.; Dejonghe, W.; Lacherez, S.; Thuy, H.T.T.; Vandecasteele, B. Phytoremediation as a management option for contaminated sediments in tidal marshes, flood control areas and dredged sediment landfill sites. Environ. Sci. Pollut. Res. 2009, 16, 745-764. [CrossRef] [PubMed]

36. Chowdhury, A.; Pradhan, S.; Saha, M.; Sanyal, N. Impact of pesticides on soil microbiological parameters and possible bioremediation strategies. Indian J. Microbiol. 2008, 48, 114-127. [CrossRef] [PubMed]

37. Kanekar, P.P.; Bhadbhade, B.J.; Deshpande, N.M.; Sarnaik, S.S. Biodegradation of organophosphorus pesticides. Proc. Indian Natl. Sci. Acad. 2004, B70, 57-70.

38. Crespi, V.; Lovatelli, A. Aquaculture in Desert and Arid Lands: Development Constraints and Opportunities; FAO Technical Workshop (Hermosillo, Mexico, 2010); Food and Agriculture Organization of the United Nations: Rome, Italy, 2011; p. 216.

39. Svintsov, I.P. Development of sandy and stony deserts. In Agricultural Land Improvement: Ameloration and Reclamation; Maslov, B.S., Ed.; EOLSS: Paris, France, 2009; Volume 1, p. 448.

40. Tang, T.; Dong, J.; Ai, S.; Qiu, Y.; Han, R. Electro-enzymatic degradation of chlorpyrifos by immobilized hemoglobin. J. Hazard. Mater. 2011, 188, 92-97. [CrossRef] [PubMed]

41. Zhang, Y.; Dong, X.; Jiang, Z.; Cao, B.; Ge, S.; Hu, M. Assessment of the ecological security of immobilized enzyme remediation process with biological indicators of soil health. Environ. Sci. Pollut. Res. 2013, 20, 5773-5780. [CrossRef] [PubMed]

42. Sirotkina, M.; Lyagin, I.; Efremenko, E. Hydrolysis of organophosphorus pesticides in soil: New opportunities with ecocompatible immobilized $\mathrm{His}_{6}-\mathrm{OPH}$. Int. Biodeterior. Biodegrad. 2012, 68, 18-23. [CrossRef]

43. Maslova, O.V.; Stepanov, N.A.; Grigoryeva, A.I.; Bruyako, M.G.; Efremenko, E.N. New effective His6-OPH-containing mineral carriers pretreated by low-temperature plasma for destruction of organophosphates in different types of soil. Int. J. Pharm. Technol. 2016, 8, 27317-27333. 
44. Eibes, G.; Arca-Ramos, A.; Feijoo, G.; Lema, J.M.; Moreira, M.T. Enzymatic technologies for remediation of hydrophobic organic pollutants in soil. Appl. Microbiol. Biotechnol. 2015, 99, 8815-8829. [CrossRef] [PubMed]

45. Lyagin, I.V.; Andrianova, M.S.; Efremenko, E.N. Extensive hydrolysis of phosphonates as unexpected behavior of the known His $_{6}$-organophosphorus hydrolase. Appl. Microbiol. Biotechnol. 2016, 100, 5829-5838. [CrossRef] [PubMed]

46. Efremenko, E.; Lyagin, I.; Gudkov, D.; Varfolomeyev, S. Immobilized biocatalysts for detoxification of neurotoxic organophosphorous compounds. Biocatal. Biotransform. 2007, 25, 359-364. [CrossRef]

47. Votchitseva, Y.A.; Efremenko, E.N.; Aliev, T.K.; Varfolomeyev, S.D. Properties of hexahistidine-tagged organophosphate hydrolase. Biochemistry 2006, 71, 167-172. [CrossRef] [PubMed]

48. Lyagin, I.V.; Efremenko, E.N.; Kabanov, A.V. Catalytic characteristics of enzyme-polyelectrolyte complexes based on hexahistidine-containing organophosphorus hydrolase. Moscow Univ. Chem. Bull. 2014, 69, 125-130. [CrossRef]

49. Efremenko, E.N.; Lyagin, I.V.; Klyachko, N.L.; Bronich, T.; Zavyalova, N.V.; Jiang, Y.; Kabanov, A.V. A simple and highly effective catalytic nanozyme scavenger for organophosphorus neurotoxins. J. Control. Release 2017, 247, 175-181. [CrossRef] [PubMed]

50. Lyagin, I.V.; Efremenko, E.N. Biomolecular engineering of biocatalysts hydrolyzing neurotoxic organophosphates. Biochimie 2018, 144, 115-121. [CrossRef] [PubMed]

51. Efremenko, E.N.; Votchitseva, J.A.; Aliev, T.K.; Varfolomeev, S.D. Recombinant Plasmid DNA pTES-His-OPH and Producer of Oligohistidine Containing Organophosphate Hydrolase. Russia Patent 2,255,975, 10 July 2005.

52. Efremenko, E.; Votchitseva, Y.; Plieva, F.; Galaev, I.; Mattiasson, B. Purification of His 6 -Organophosphate hydrolase using monolithic supermacroporous polyacrylamide cryogels developed for immobilized metal affinity chromatography. Appl. Microbiol. Biotechnol. 2006, 70, 558-563. [CrossRef] [PubMed]

53. Pevgov, V.G. Method of Plasmachemical Treatment of Raw Stock of Organic or Vegetable Origin and Device to This End. Russia Patent 2,448,768 C2, 27 April 2012.

54. Efremenko, E.N.; Sirotkina, M.S.; Lyagin, I.V. Method for Enzymatic Hydrolysis of Organophosphorus Soil Compounds. Russia Patent 2,451,077, 20 May 2012.

55. Skoog, D.A.; West, D.M.; Holler, F.J.; Crouch, S.R. Fundamentals of Analytical Chemistry, 9th ed.; Brooks/Cole: Pacific Grove, CA, USA, 2014; p. 1090.

56. Frische, T.; Höper, H. Soil microbial parameters and luminescent bacteria assays as indicators for in situ bioremediation of TNT-contaminated soils. Chemosphere 2003, 50, 415-427. [CrossRef]

57. Efremenko, E.N.; Maslova, O.V.; Kholstov, A.V.; Senko, O.V.; Ismailov, A.D. Biosensitive element in the form of immobilized luminescent photobacteria for detecting ecotoxicants in aqueous flow-through systems. Luminescence 2016, 31, 1283-1289. [CrossRef] [PubMed]

58. Bangira, C.; Loeppert, R.H.; Moore, T.J.; Hons, F.M.; Shahandeh, H. Relative effectiveness of $\mathrm{CaCO}_{3}$ and $\mathrm{Ca}(\mathrm{OH})_{2}$ in minimizing metals solubility in contaminated sediment. J. Soils Sediment 2017, 17, 1796-1805. [CrossRef]

59. Kishore, B.K.; Lambricht, P.; Laurent, G.; Maldague, P.; Wagner, R.; Tulkens, P.M. Mechanism of protection afforded by polyaspartic acid against gentamicin-induced phospholipidosis. II. Comparative in vitro and in vivo studies with poly-L-aspartic, poly-L-glutamic and poly-D-glutamic acids. J. Pharmacol. Exp. Ther. 1990, 255, 875-885. [PubMed]

60. Neumann, G.; Bott, S.; Ohler, M.A.; Mock, H.P.; Lippmann, R.; Grosch, R.; Smalla, K. Root exudation and root development of lettuce (Lactuca sativa L. cv. Tizian) as affected by different soils. Front. Microbiol. 2014, 5, 2. [CrossRef] [PubMed]

61. Ware, G.W. Reviews of Environmental Contamination and Toxicology: Continuation of Residue Reviews; Springer: New York, NY, USA, 1993; Volume 131, p. 154.

62. Mansee, A.H.; Chen, W.; Mulchandani, A. Detoxification of the organophosphate nerve agent coumaphosusing organophosphorus hydrolase immobilized on cellulose materials. J. Ind. Microbiol. Biotechnol. 2005, 32, 554-560. [CrossRef] [PubMed]

63. Ippolito, J.A.; Tarkalson, D.D.; Lehrsch, G.A. Zeolite soil application method affects inorganic nitrogen, moisture, and corn growth. Soil Sci. 2011, 176, 136-142. [CrossRef] 
64. Dercová, K.; Sejáková, Z.; Skokanová, M.; Barančíková, G.; Makovníková, J. Potential use of organomineral complex (OMC) for bioremediation of pentachlorophenol (PCP) in soil. Int. Biodeterior. Biodegrad. 2006, 58, 248-253. [CrossRef]

65. Liang, Y.; Zhang, X.; Dai, D.; Li, G. Porous biocarrier-enhanced biodegradation of crude oil contaminated soil. Int. Biodeterior. Biodegrad. 2009, 63, 80-87. [CrossRef]

66. Bruyako, M.G.; Glukhoedov, V.A.; Kravtsova, D.; Smirnov, V.A.; Ushkov, V.A. Plasma processing in industry of building materials. Adv. Mater. Res. 2014, 1040, 730-734. [CrossRef]

67. Bruyako, M.; Grigorieva, L.; Grigorieva, A.; Ivanova, I. Treatment of natural zeolites for increasing the sorption capacity. Mater. Sci. Forum 2016, 871, 70-75. [CrossRef]

68. Liu, C.J.; Vissokov, G.P.; Jang, B.W.L. Catalyst preparation using plasma technologies. Catal. Today 2002, 72, 173-184. [CrossRef]

69. Yang, C.; Liu, N.; Guo, X.; Qiao, C. Cloning of mpd gene from a chlorpyrifos-degrading bacterium and use of this strain in bioremediation of contaminated soil. FEMS Microbiol. Lett. 2006, 265, 118-125. [CrossRef] [PubMed]

70. Lakshmi, C.V.; Kumar, M.; Khanna, S. Biodegradation of chlorpyrifos in soil by enriched cultures. Curr. Microbiol. 2009, 58, 35-38. [CrossRef] [PubMed]

71. Kipnis, E.; Sawa, T.; Wiener-Kronish, J. Targeting mechanisms of Pseudomonas aeruginosa pathogenesis. Med. Mal. Infect. 2006, 36, 78-91. [CrossRef] [PubMed]

72. Hota, S.; Hirji, Z.; Stockton, K.; Lemieux, C.; Dedier, H.; Wolfaardt, G.; Gardam, M.A. Outbreak of multidrug-resistant Pseudomonas aeruginosa colonization and infection secondary to imperfect intensive care unit room design. Infect. Control Hosp. Epidemiol. 2009, 30, 25-33. [CrossRef] [PubMed]

73. Abbas, M.; Hafeez, F.; Ali, A.; Farooq, M.; Latif, M.; Saleem, M.; Ghaffar, A. Date palm white scale (Parlatoria blanchardii T): A new threat to date industry in Pakistan. J. Entomol. Zool. Stud. 2014, 2, 49-52.

(C) 2017 by the authors. Licensee MDPI, Basel, Switzerland. This article is an open access article distributed under the terms and conditions of the Creative Commons Attribution (CC BY) license (http://creativecommons.org/licenses/by/4.0/). 